\title{
Asthma Genetics and Intermediate Phenotypes: A Review From Twin Studies
}

\author{
H. Los ', P. E. Postmus ${ }^{2}$, and D. I. Boomsma ${ }^{3}$ \\ 'Department of Pulmonary Medicine, Refaja Hospital, Stadskanaal,The Netherlands. \\ ${ }^{2}$ Department of Pulmonary Medicine, Academic Hospital, Free University Amsterdam, The Netherlands. \\ ${ }^{3}$ Department of Biological Psychology, Free University Amsterdam, The Netherlands.
}

\begin{abstract}
t has been long recognised that asthma and related phenotypes have an important hereditary nature, in which inheritance does not follow the classical Mendelian patterns and the exact mode of inheritance is not known. Linkage, association studies and genome-wide screening suggest that many genes are involved in the pathogenesis of asthma. Twin studies have contributed significantly to our understanding on the genetics of asthma, especially the large-scale twin studies in different parts of the world which have showed comparable results. With the shortcomings of the twin method borne in mind, more twin studies are needed to investigate the heredity component of the intermediate phenotypes of asthma, that is, bronchial hyperresponsiveness, total immunoglobulin E, skin test reactivity, specific IgE against different aeroallergens, and the variability of lung function. Twin studies are very suitable to unravel the intricate network of genes and environment which plays a role in asthma. Monozygotic twins and the co-twin control design are suitable for this purpose, while longitudinal twin studies are needed to solve the problem of the age related expression of genes which probably are involved in the pathogenesis of asthma. In the near future twin studies will play an important role in the detection of new, as yet undiscovered genes, but may be even more important in answering the most challenging of all questions: how do the environment interact with the genetics of asthma? Exchange of information and collaboration between the different research groups involved in the genetics of asthma will contribute to a better understanding of this condition.
\end{abstract}

Asthma is a common disease which affects many people all over the world. Since the nineteenth century it has been known as "episodic dyspnoe with healthy respiration between attacks caused by spasm of the bronchi”. Asthma and the associated clinical disorders atopy, rhinitis and eczema are strongly familial and are due to genetic and environmental influences. The inheritance of asthma does not follow the classical Mendelian patterns, which are characteristic of single-gene disorders. Rather, like diseases such as hypertension, atherosclerosis and diabetes mellitus, it is a complex genetic disorder in which the mode of inheritance cannot be classified as autosomal, recessive or sex-linked. Another important aspect that often distinguishes complex genetic disorders from single gene disorders is their prevalence. Asthma is more common in the population (4-8\%) than, for example, cystic fibrosis which occurs once in every 2,000 live Caucasians births (Sandford et al., 1996).
The genetic complexity of asthma may include that a number of genes are involved in its pathogenesis (polygenetic inheritance), that different combinations of genes act in different families (genetic heterogeneity) and that the same gene or sets of genes influences multiple traits (pleiotropy) for example, asthma and eczema. Furthermore, environmental influences could be of importance for the expression of asthma.

Studies on the genetics of asthma are complicated by the fact that there are difficulties in standardising the diagnosis of asthma. Nowadays asthma is considered as an inflammatory disease in the conducting airways of the lungs and eosinophilia with variable airway obstruction, which may lead to tissue destruction and loss of lung function (American Thoracic Society, 1987; Bousquet et al., 1990; Holgate, 1997; Meneely et al., 1962). Different clinical forms of asthma exist such as allergic (extrinsic) asthma, asthma without evidence of atopy (intrinsic), earlyand late-onset asthma, occupational and exercise-induced asthma.

Although asthma occurs throughout the world, large geographical and ethnic differences in asthma prevalence have been reported, varying from $0.5 \%$ to $6 \%$ (Kerkhof et al., 1994; Platts-Mills \& Carter, 1997; Rijcken et al., 1996; Turkeltaub et al., 1991; Woolcock et al., 1987), and countries are classified by their asthma rates into low incidence countries (Africa and Asia), medium incidence countries (USA, Canada, European countries and the United Kingdom) and high incidence countries (New Zealand and Australia) (Burney et al., 1996). Different prevalences have been found in urban and rural areas. In a population in Zimbabwe, exercise-induced asthma was associated with urban residence and high living standards (Keeley et al., 1991). The offspring of Tokelauans who had migrated to New Zealand had increased prevalences of asthma compared to their relatives who remained in Tokelau (Waite et al., 1980). In Japan, asthma prevalence has increased since the population moved away from well-ventilated houses to the Western-style buildings (Cookson \& Moffatt, 1997),

Address for correspondence: Professor D.I. Boomsma, Department of Biological Psychology, Free University, De Boelelaan 1111, $1081 \mathrm{HV}$ Amsterdam, The Netherlands. E-mail: Dorret@psy.vu.nl

Received 30 November 2000, accepted 22 December 2000 
and a recent study among children in a city in former West Germany (Munich) and two cities in former East Germany (Halle and Leipzich) has shown that asthma and atopy were significantly more frequent in children in former West Germany (Von Mutius et al., 1994). Thus it appears that the prevalence of asthma is subject to Westernization, and data suggest also an increase in asthma in the Western world over the last 20 years (Burr et al., 1989; Ninan \& Russell, 1992; Peat et al., 1994; Robertson et al., 1991; Waite et al., 1980). It is unlikely that there is a change in genetic make-up over such a short period of time, rather the increase in asthma prevalences could be explained in terms of environment with increasing exposure levels to indoor or outdoor pollution, smoking behaviour, occupation or the decline of many infectious diseases as a result of high living standards and immunisation programs (Newman-Taylor, 1995). Although environmental influences are important to the development of asthma, the familial nature of the disease suggests that one must have a genetic ability to respond to environmental influences. The purpose of this review is to give some insight into the genetics of asthma and the way in which twin studies have been used to study the architecture of asthma and associated phenotypes.

\section{Asthma Phenotype}

Most genetic studies have concentrated on asthma associated with atopy. Atopy is defined in a number of different ways: by elevated total serum IgE-levels and/or positive skintests to one or more allergens. The binding of IgE with both high-affinity and low-affinity receptors provides a signal for mast cell activation and eosinophil recruitment. An inflammatory process involving the release of inflammatory mediators (prostaglandins, leucotrienes and proteolytic enzymes) may lead to tissue destruction, epithelial disruption, smooth muscle and microvascular proliferation, which eventually lead to an an bronchoconstrictor response and bronchial hyperresponsiveness of the airways to chemical stimuli (see Figure 1; Holgate, 1997).

Defining the phenotype correctly is an important issue in genetic studies. In asthma it appears quite difficult, since several clinical entities exist. Many epidemiological and genetic studies assess the asthma phenotypes by means of questionnaire data, reported doctor's diagnosis of asthma, bronchial hyperresponsiveness or combinations of the earlier mentioned parameters (Howard et al., 1999; Panhuysen et al., 1998). Questionnaires are frequently used in large-scale studies, and although the validity of questionnaires is relatively good (Enarson et al., 1987; Mensinga et al., 1990), there is a possibility of overestimation or underestimation of the asthma prevalence (Cerveri et al., 1987; De Marco et al., 1998). Furthermore, there can be diagnostic bias because misclassification with other obstructive lung diseases is not uncommon (Martinez et al., 1995). Because of these problems and the lack of a clearly defined asthma phenotype, researchers have moved away to measurable biological markers (intermediate phenotypes) such as total immunoglobulin E, specific IgE against common allergens, bronchial hyperresponsiveness, eosinophilia, lung function and peak flow variability (Martinez, 1997).

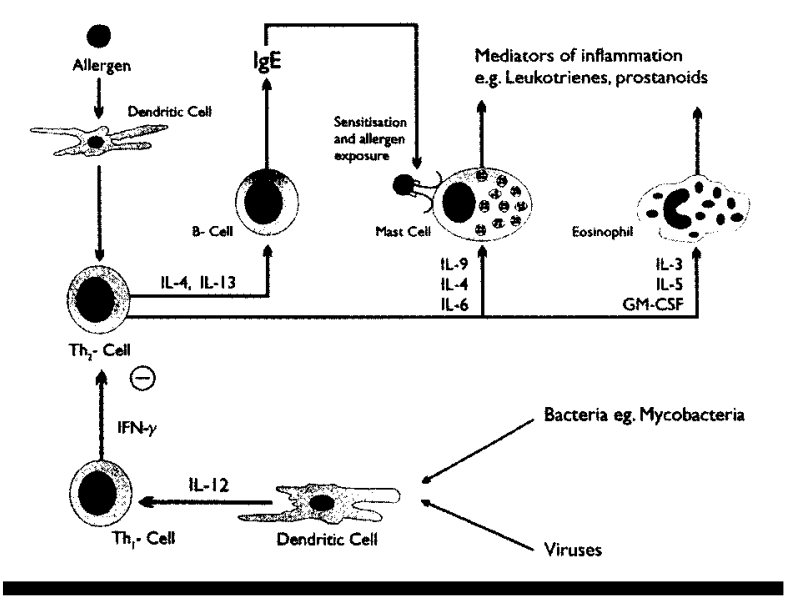

Figure 1

Inflammatory process in asthma: allergen uptake and processing by dendritic cells, presentation of peptides to the T-cell receptor, different molecules provides a signal for the Th- 0 cel to differentiate into Th-1 or Th-2 cells. These cells have the ability to produce cytokines which are involved in the pathogenesis of asthma (Th-2). Exposure to viruses or bacteria like Mycobacteria may adopt a different response ( Th-1), which may lead to a phenotype against asthma. (Figure reproduced by permission, Holgate, 1997).

Another problem in defining the asthma phenotype is that the clinical expression of asthma may vary over time even within an individual, especially at older age. Thus lack of a gold standard to diagnose asthma, variable clinical expression, variable age at onset and variable progression during lifetime are providing some difficulties in the studies on the genetics of asthma (Martinez, 1997; Postma et al., 1998).

\section{Genetic Contribution to Asthma}

It has been known for a long time that genetic influences play an important role in the pathogenesis of asthma. It was not until the early 1900s that several family studies showed evidence for a substantial familial aggregation in asthma (Cooke \& van der Veer, 1916; Drinkwater, 1909; Rackemann, 1928; Schwartz, 1952; Spain \& Cooke, 1924). Although these studies were important to assess the familial component of asthma, they could not estimate heritabilities to analyse the pattern of inheritance. From the eighties, segregation analysis has further developed the understanding on the genetics of asthma. This statistical method is used to analyse the pattern of inheritance by observing how the trait is distributed in families, by comparing the number of affected individuals with the expected numbers under different genetic models. The genetic models include dominant, recessive, mixed models and models with environmental influences. The model which fits the data best is the one which adequately describes the segregation of a trait in the families (Cantor \& Rotter, 1992; Khoury et al., 1993). Many segregation analyses on asthma have been carried out mostly by using questionnaires (Chen et al., 1998; European Community Respiratory Health Group, 1997; Holberg et al., 1996; Jenkins et al., 1997; Lawrence et al., 1994) and total immunoglobulin E (Gerrard et al., 1978; Hasstedt et al., 1983; Meyers et al., 1987; Panhuysen \& Meyers, 1996), 
but only two segregation analyses on bronchial hyperresponsiveness have been published (Lawrence et al., 1994; Townley et al., 1986). These studies have come to varying conclusions regarding the pattern of inheritance: mixed models, co-dominant inheritance, single locus and contribution of polygenes and environment were found in the questionnaire-based studies on asthma scores, doctor's diagnosis of asthma and wheeze. In the total immunoglobulin E studies evidence for a major gene was found in several studies in different countries but the mode of inheritance is still unclear.

In the last fifteen years molecular genetics has been developed extensively, and has been used to identify which genes may cause asthma. Since the existence of different phenotypes of asthma, and the intricate immunological network which is involved in the pathogenesis of asthma, it is hypothesised that different genes are responsible for this disease. Different approaches have been used to detect genes which are involved in asthma. Genetic linkage is the analysis of the inheritance of genetic markers within pedigrees to establish linkage between a marker and the disease. Linkage analysis requires a genetic model to be specified, and the mode of inheritance, allele frequencies and penetrance to be known (Khoury et al., 1993). A more robust form of linkage analysis in which there is no need for a specific genetic model is the sib-pair or affected relative pair method. This method tests if the inheritance of a chromosomal region is consistent with random segregation, and is performed by testing whether affected relatives share identical copies of alleles more often than expected by chance (Khoury et al., 1993; Morton, 1955). Candidate-gene approaches investigate the association between region of genes whose function may be relevant to the disease, by comparing the genotypes between cases with disease and controls, either within or between families (Manian, 1997; Short, 1997).

In the last fifteen years, many genetic studies have identified chromosomal regions that may contain genes that contribute to asthma or associated phenotypes. Linkage for high levels of total $\operatorname{IgE}$ has been found on chromosome $5 \mathrm{q}$ (Doull et al., 1996; Marsh et al., 1994; Meyers et al., 1994; Noguchi et al., 1997), chromosome 11q (Collee et al., 1993; Cookson et al., 1989; Moffatt et al., 1992), and chromosome 12q (Barnes et al., 1996). Bronchial hyperresponsiveness, another phenotype of asthma, has shown linkage to chromosome 5q (Hall et al., 1995; Postma et al., 1995), while other chromosomal regions (6p21.3, $12 \mathrm{q} 14.3-24.1$ and $14 \mathrm{q} 11.2-13$ ) are involved in the immunological network associated with asthma. Until now, four genome-wide screens have significantly contributed to our understanding of the genes associated with asthma and associated phenotypes. Different populations have been studied: Western Australia, United Kingdom, three ethnic groups from the United States, the Hutterites, and families recruited from The Netherlands ("A genome-wide search for asthma susceptibility loci in ethnically diverse populations", 1997; Daniels et al., 1996; Koppelman et al., 1998; Ober et al., 1998). The outcome of these genome-wide screens showed evidence of linkage in at least more than one population, involving chromosomes 5q, 6p, 11q, 12q and 13q. The mode of inheritance is still unknown, as is the identity of the genes which lead to the susceptibility to asthma.

\section{Contribution of Twin-studies to the Genetics of Asthma}

Another widely used design to study the genetics of complex traits is by using twins, in which the resemblance between identical (monozygotic) is compared with fraternal (dizygotic) twins. Monozygotic twins share $100 \%$ of their genetic make-up and dizygotic twins share on average $50 \%$ of their genes like other siblings. If genes influence a particular trait, then because of the greater genetic similarity, monozygotic twins should resemble each other to a greater extent than dizygotic twins. This classical twin study can be extended with dizygotic twins of unlike sex, which provides a way of assesing the extent to which individual differences are due to the same genetic influences in male and female twins. When different genes account for the variance in male and female twins, dizygotic unlike pairs will have a smaller correlation for a particular trait than that in samesex pairs. Another important goal in the study of twins is the estimation of the effects of environmental influences, because resemblance between twins can be due to environmental influences that they have in common: shared environment (e.g. parental influences, school). Environmental influences which effects are specific for a person (within family or unique environment) will contribute to differences between individuals with the same genetic make-up if they are reared in the same family.

One of the assumptions of the classical twin-design is that the environment is equal for both monozygotic and dizygotic twins. If this is not the case, and monozygotic twins would experience more similar environment than dizygotic twins, this would lead to a higher heritability of a trait than expected. This assumption may not be valid in case of asthma, as it has been shown that monozygotic twins have more similar smoking patterns than dizygotic twins (Carmelli et al., 1992). It is not known if monozygotic twins share more similar environmental influences like exposure to indoor allergens and viruses. However, there is much evidence that the equal environment assumption is correct for many behavioral traits (Hettema et al., 1995; Kendler, 1993). Other assumptions made in twin studies are: monozygotic and dizygotic twins are samples of the same gene-pool; twins are representative of the population; and self reported zygosity is correct in questionnairebased studies (Boomsma et al., 1993; Chen et al., 1999). An extension of the classical twin study with parental information makes it possible to assess the effects of parental influences on offspring (cultural transmission) and to study assortive mating for the disorder. Table 1 presents results of population-based twin studies.

\section{Population-based Studies on Asthma}

One of the first and largest twin studies was performed by Edfors-Lubs (1971) from the Swedish Twin Registry, in which 6996 adult twin pairs between 46 and 85 years old were studied. In this study the monozygotic concordance 
Table 1

Twin Studies of Asthma

\begin{tabular}{|c|c|c|c|c|c|c|c|c|c|}
\hline Study & Population & $\begin{array}{l}\text { Age range } \\
\text { (years) }\end{array}$ & Zygosity & $P(\%)$ & $r_{\mathrm{Mz}}$ & $r_{\mathrm{Dz}}$ & $\mathrm{h}$ & Genetic model & Comments \\
\hline Edfors-Lubs (1971) & Swedish & $46-85$ & $\begin{array}{l}\text { MZ:2434 } \\
\text { DZ: } 4302\end{array}$ & 3.8 & 0.65 & 0.25 & 0.65 & & $\begin{array}{l}\text { Population study } \\
\text { Self reported asthma. } \\
\text { Same-sex twin pairs }\end{array}$ \\
\hline Hopper (1990) & Australian & $18-66+$ & $\begin{array}{l}\text { MZM:567 } \\
\text { MZF:1232 } \\
\text { DZM:352 } \\
\text { DZF:751 } \\
\text { DZ0:906 }\end{array}$ & 13 & & & 0.60 & & $\begin{array}{l}\text { Population study } \\
\text { Self reported asthma }\end{array}$ \\
\hline Niemienen (1991) & Finnish & $18-70+$ & $\begin{array}{l}\text { MZ:4307 } \\
\text { DZ: } 9581\end{array}$ & & 0.43 & 0.25 & 0.36 & & $\begin{array}{l}\text { Population study } \\
\text { Doctor's diagnosis } \\
\text { of asthma. } \\
\text { Same-sex twin pairs }\end{array}$ \\
\hline Duffy (1990) & Australian & $18-88$ & $\begin{array}{l}\text { MZM:567 } \\
\text { MZF:1232 } \\
\text { DZM:352 } \\
\text { DZF: } 751 \\
\text { DZ0:906 }\end{array}$ & 13 & 0.65 & 0.24 & $\begin{array}{l}0.60 \\
0.75\end{array}$ & $\begin{array}{l}\text { Males: ADE } \\
\text { females: AE } \\
\text { model fits } \\
\text { data best }^{*}\end{array}$ & $\begin{array}{l}\text { Population study } \\
\text { Self reported asthma }\end{array}$ \\
\hline Harris (1997) & Norwegian & $18-25$ & $\begin{array}{l}\text { MZM:412 } \\
\text { DZM:384 } \\
\text { MZF:527 } \\
\text { DZF: } 442 \\
\text { DZ0:794 }\end{array}$ & & 0.75 & 0.21 & 0.75 & $\begin{array}{l}A D E \text { and } A E \\
\text { fits data best }\end{array}$ & $\begin{array}{l}\text { Population study } \\
\text { Self reported asthma }\end{array}$ \\
\hline Laitinen (1998) & Finnish & 16 & $\begin{array}{l}\text { MZM:211 } \\
\text { MZF: } 324 \\
\text { DZM:285 } \\
\text { DZF: } 272 \\
\text { DZO:621 }\end{array}$ & $3-11$ & 0.76 & 0.45 & 0.79 & $\begin{array}{l}\text { AE model fits } \\
\text { data best } \\
\text { in twins* }\end{array}$ & Parental-twin design \\
\hline Lichtenstein (1997) & Swedish & $7-9$ & $\begin{array}{l}\text { MZM:211 } \\
\text { MZF: } 210 \\
\text { DZM:223 } \\
\text { DZF: } 246 \\
\text { DZ0:387 }\end{array}$ & & & & $\begin{array}{l}0.70- \\
0.76\end{array}$ & $\begin{array}{l}\text { AE model fits } \\
\text { data best* }\end{array}$ & $\begin{array}{l}\text { Parent-reported asthma. } \\
\text { Questionnaire based } \\
\text { population study }\end{array}$ \\
\hline Skadhauge (1999) & Danish & $12-41$ & $\begin{array}{l}\text { MZM:1677 } \\
\text { MZF: } 2013 \\
\text { DZM:1677 } \\
\text { DZF: } 2228 \\
\text { DZO:3651 }\end{array}$ & & & & 0.73 & $\begin{array}{l}\text { AE model fits } \\
\text { data best* }\end{array}$ & $\begin{array}{l}\text { Population study } \\
\text { Self reported asthma }\end{array}$ \\
\hline Becgher (submitted) & Dutch & $12-24$ & $\begin{array}{l}\text { MZM:397 } \\
\text { MZF: } 536 \\
\text { DZM:349 } \\
\text { DZF: } 416 \\
\text { DZO: } 661\end{array}$ & $\begin{array}{l}10.7- \\
13.5\end{array}$ & 0.78 & 0.45 & 0.72 & $\begin{array}{l}\text { AE model fits } \\
\text { data best* }\end{array}$ & Parental-Twin design \\
\hline
\end{tabular}

Notes: A: additive genetic effects, D: dominant genetic effects, C: shared environment, E: non-shared environment

$\mathrm{h}$ : heritability, $r_{\mathrm{MZ}}: \mathrm{MZ}$ twin correlation. $r_{\mathrm{DZ}}: \mathrm{DZ}$ twin correlation

*in these studies no evidence for shared environment. P: prevalence. 
rate for self reported asthma was $19 \%$ and the dizygotic concordance rate was $4.8 \%$. There was no difference in asthma symptom prevalence between men and women, and there was no significant age trend in self-reported asthma. Although the large monozygotic-dizygotic concordance ratio is suggestive of dominance inheritance, no distinction could be made on the inheritance of asthma.

A large Australian study from the National Health Medical Research Council Twin Registry investigated 3808 twin pairs (567 MZM, 352 DZM, $1232 \mathrm{MZF} 751$ DZF and 906 DZO) (Hopper et al., 1990). The prevalence for asthma was $13 \%$ with no significant age trend in the different age groups (18-65+ years). The tetrachoric correlations for asthma were much greater for monozygotic twins than for dizygotic twins ( 0.48 for MZM, 0.09 for DZM and 0.33 for MZF, 0.12 for DZF) implying that there is a significant proportion of the variance accounted by genetic factors in the pathogenesis of asthma. The cross correlations of the two self reported traits (asthma and allergy) were 0.20 in monozygotic twins and 0.07 in dizygotic twins, and it was concluded that the correlation between asthma and allergy was accounted for by common genetic factors.

In 1991, Nieminen et al published a population-based study of 13888 adult Finnish monozygotic and same sex dizygotic twin pairs. The diagnosis of asthma was made by linking the twin registries with databases on hospital admission, usage of medication and death certificates from the central statistical office. A total of 4307 monozygotic and 9581 dizygotic twin pairs aged 18-70+ were studied. The prevalence for asthma was $1.9 \%$ in the whole population. In the group aged 28-59 years the prevalence was higher than in the group aged over 60 years (1.2\% vs $0.7 \%)$. Using this "clinical" definition, the recurrence risk for asthma on monozygotic male and female twins were $8.2 \%$ and $16.25 \%$, and for the dizygotic twins $8.5 \%$ and $4.9 \%$ respectively. Using the multifactorial threshold model, correlations in liability were the highest were in monozygotic females and the lowest in dizygotic females. The heritability estimate was 0.68 in women and 0.48 in men (aged 28-59). Combining the sexes, the heritability was 0.36 . In this study there was a marked gender difference in heritability and there was a difference in heritability between the various agegroups, with heritability decreasing with age.

Duffy et al. (1990) reanalysed the population of 3808 Australian twin pairs which were already studied by Hopper et al. (1990). This study was one of the first biometric analyses on the genetics of asthma. The prevalence of ever-reported asthma was $13.2 \%$. There were no differences in prevalence between the various age groups. The correlation of self reported asthma was 0.65 among monozygotic twins and 0.24 among dizygotic twins, and the heritability was 0.60 for females and 0.75 for males. Genetic modelling showed that the nonadditive component made a large contribution in males but not in females, in whom additive genetic effects contributed to the observed variance to a large extent. Still $25-40 \%$ of the observed variance was accounted to environmental influences but there was no evidence for shared environment.
A study from the Swedish Twin Registry involved 1480 Swedish twin pairs aged 7-9 years (Lichtenstein \& Svartengren, 1997). This questionnaire-based study examined the importance of genetic and shared environmental influences in atopic diseases. All parents of twins born in Sweden between April 1985 and December 1986 were mailed a detailed questionnaire on asthma and allergies. The correlation for parental-report of asthma was 0.79 for monozygotic male twin pairs and 0.64 for monozygotic female pairs, with correlations of 0.25 and 0.27 for dizygotic male and female pairs respectively. The contribution of genetic factors to variance of asthma was about 0.76 for boys and 0.64 for girls. Genetic modelling showed no evidence of shared environment in both sexes. The genetic correlation between asthma and allergy was 0.90 , indicating that there are sets of genes common for these traits.

Harris et al. published a study of 5864 Norwegian twins who participated in a study on health and development in Oslo (Harris et al., 1997). All twins born between 1967 and 1974 were identified through the National Medical Birth Registry The prevalence for self reported asthma was $5.7 \%$ and there were no sex differences. However the average age at onset was lower in the male twins with asthma than in the female twins with asthma. The probandwise concordance for asthma was 0.45 for monozygotic twins and 0.12 for dizygotic twins. In the monozygotic twins whose co-twin had a positive history of asthma, the risk of developing asthma was 22.5 times greater among the male twins and 13.8 times greater among the female twins. The corresponding values for the dizygotic same-sex twins were significantly lower. Genetic modelling showed that genetic effects explained $75 \%$ of the variation in both sexes. The remaining $25 \%$ was accounted for by environmental influences, with no evidence for shared environment.

A Finnish twin study in 16-year-old twins and their parents presented combined twin-family data on the genetics of asthma. The heritability of asthma was approximately $79 \%$ and the remaining $21 \%$ was due to environmental influences with no evidence for shared environment (parental status ignored) (Laitinen et al., 1998). In families with parental asthma, genetic influences explained as much as $87 \%$ of the development of asthma in the offspring. The cumulative incidence was fourfold in twins with parental asthma when compared with the incidence of asthma in twins without parental asthma (14.7\% versus $3.3 \%)$.

A large-scale study on 11688 twin pairs aged 12-41 years was published by Skadhauge et al. (1999). The same results were found as in the twin studies described above. The heritability was 0.73 and the model incorporating additive genetic effects with nonshared environment was the best fitting model. These studies have shown the importance of genetic influences in the variance of asthma, but environmental influences are important since they contribute at least $25 \%$ of the total variance of asthma. An important finding is that most of these twin studies in different parts of the world showed the same results, with no evidence of shared environment. The estimates of heritability in the twin studies are consistent with those from family studies. No age-specific heritability estimates are available. 
Table 2

Twin Studies of Bronchial Hyperresponsiveness and Immunoglobulin-E

\begin{tabular}{|c|c|c|c|c|c|c|c|c|}
\hline Study & Population & $\begin{array}{l}\text { Age range } \\
\text { (years) }\end{array}$ & Zygosity & $\mathrm{P}(\%)$ & $r_{\mathrm{Mz}}$ & $\mathrm{h}$ & Genetic model & Comments \\
\hline \multicolumn{9}{|l|}{ BHR } \\
\hline König (1974) & Israel & $3-40$ & $\begin{array}{l}\mathrm{MZ}: 8 \\
\mathrm{DZ}: 7\end{array}$ & & & & & $\begin{array}{l}\text { Small study } \\
\text { Concordance MZ > DZ }\end{array}$ \\
\hline Hopp (1984) & USA & $6-31$ & $\begin{array}{l}\text { MZ:61 } \\
\mathrm{DZ}: 46\end{array}$ & 0.67 & 0.34 & 0.66 & & No genetic modelling \\
\hline \multicolumn{9}{|l|}{$\lg \mathrm{E}$} \\
\hline Bazaral (1974) & USA & $\begin{array}{l}45-55 \\
2-10\end{array}$ & $\begin{array}{l}M Z: 54 \\
D Z: 39 \\
M Z: 10 \\
D Z: 13\end{array}$ & & & $\begin{array}{l}0.58 \\
0.79\end{array}$ & $\begin{array}{l}\text { AE fits data } \\
\text { best }^{*}\end{array}$ & Heritability children 0.79 \\
\hline Wüthrich (1981) & Switzerland & & $\begin{array}{l}\mathrm{MZ}: 30 \\
\mathrm{DZ}: 20\end{array}$ & & & & & $\begin{array}{l}\text { Concordance MZ } 56.7 \% \\
\text { Concordance DZ } 20 \% \\
\text { One or both twins history } \\
\text { of atopy }\end{array}$ \\
\hline Hopp (1984) & USA & $6-31$ & $\begin{array}{l}\text { MZ:61 } \\
\mathrm{DZ}: 46\end{array}$ & 0.82 & 0.52 & 0.61 & & No genetic modelling \\
\hline Hanson (1991) & USA & $17-43$ & $\begin{array}{l}\mathrm{MZ}: 34 \\
\mathrm{DZ}: 29\end{array}$ & 0.42 & 0.26 & 0.51 & $\begin{array}{l}\text { AE fits data } \\
\text { best }\end{array}$ & $\begin{array}{l}\text { Reared together } \\
\text { Genetic model: } \\
\text { population } \\
\text { combined with Finnish } \\
\text { population }\end{array}$ \\
\hline Hanson (1991) & USA & $26-53$ & $\begin{array}{l}M Z: 53 \\
D Z: 21\end{array}$ & 0.64 & 0.49 & & & Reared apart \\
\hline Hanson (1991) & Finland & $22-51$ & $\begin{array}{l}\mathrm{MZ}: 76 \\
\mathrm{DZ}: 82\end{array}$ & 0.56 & 0.37 & 0.51 & $\begin{array}{l}\text { AE fits data } \\
\text { best }\end{array}$ & $\begin{array}{l}\text { Reared together } \\
\text { Genetic model: } \\
\text { population } \\
\text { combined with USA } \\
\text { population }\end{array}$ \\
\hline
\end{tabular}

* reanalysed by Duffy

In most of these large-scale twin studies the diagnosis of asthma was based on self-report. Several twin studies have been carried out on intermediate phenotypes of asthma such as bronchial hyperresponsiveness, total immunoglobulin E, skin test reactivity, specific $\operatorname{IgE}$ and lung function. Tables 2, 3 and 4 presents results of twin studies and intermediate phenotypes.

\section{Bronchial Hyperresponsiveness}

Very few twin studies contain data on bronchial hyperresponsiveness. A study on 8 monozygotic and 7 dizygotic twin pairs, aged 3-40 years old, on exercise-induced bronchial hyperresponsiveness and skin test reactivity showed a significant higher concordance in the monozygotic twinpairs $(75 \%)$ than in the dizygotic twinpairs (14\%) (König and Godfrey, 1974). In 1984, Hopp et al. examined 107 twin pairs recruited from the outpatient clinic and via media advertising. Sixty-one monozygotic and 46 dizygotic pairs aged 6-31 years were examined for bronchial hyperresponsiveness for methacholine and skin test reactivity to allergens, and total $\mathrm{IgE}$ levels were measured. The correlation $(r)$ of bronchial hyperresponsiveness for the monozygotic and dizygotic twins was based on the analysis of variance by Haseman and Elston (1970) and the heritability was determined by

$$
\mathrm{h}=2\left(r_{\mathrm{MZ}}-r_{\mathrm{DZ}}\right) \text {. }
$$

The intraclass correlations for bronchial hyperresponsiveness were significantly higher for the monozygotic twins than for the dizygotic twins ( 0.67 and 0.34 respectively). This gives a heritability estimate of 0.66 , suggesting bronchial hyperresponsiveness plays a role in the genetics of asthma. No genetic modelling was carried out and no statement on the mode of inheritance could be made.

\section{Immunoglobulin E}

Bazaral et al. (1974) studied 54 monozygotic twin pairs and 39 dizygotic twin pairs aged 45-55 years old from the National Research Council's Twin Registry California. An additional sample of 23 twin pairs (10 monozygotic pairs and 13 dizygotic pairs) aged 2-10 years old were also examined. Zygosity was based on serotyping. Genetic effects were found for $\operatorname{IgE}$ in the adult twins, with a heritability estimate of 0.58 , and a heritability of 0.79 was found for the children (confidence interval 44\%-93\%). According to this data, genetic influences may be of more importance in children than in adults. Reanalysis of this data using LISREL by Duffy (1994) showed a heritability 
Table 3

Twin Studies of Skin Test Reactivity and Specific IgE

\begin{tabular}{|c|c|c|c|c|c|c|c|}
\hline Study & Population & $\begin{array}{l}\text { Age range } \\
\text { (years) }\end{array}$ & Zygosity & $r_{\mathrm{Mz}}$ & $r_{\mathrm{Dz}}$ & $\mathrm{h}$ & Comments \\
\hline \multicolumn{8}{|l|}{ Skin Test } \\
\hline Hopp (1984) & USA & $6-31$ & $\begin{array}{l}\mathrm{MZ}: 61 \\
\mathrm{DZ}: 46\end{array}$ & 0.82 & 0.46 & 0.72 & No genetic modelling \\
\hline Hanson (1991) & USA & $17-43$ & $\begin{array}{l}\mathrm{MZ}: 34 \\
\mathrm{DZ}: 29\end{array}$ & 0.70 & 0.28 & & $\begin{array}{l}\text { No genetic modelling } \\
\text { Reared together }\end{array}$ \\
\hline Hanson (1991) & USA & $26-53$ & $\begin{array}{l}\text { MZ:53 } \\
\mathrm{DZ}: 21\end{array}$ & 0.55 & 0.50 & & $\begin{array}{l}\text { No genetic modelling } \\
\text { Reared apart }\end{array}$ \\
\hline \multicolumn{8}{|l|}{ Specific IgE } \\
\hline Wüthrich (1981) & Switzerland & & $\begin{array}{l}\text { MZ:30 } \\
\mathrm{DZ}: 20\end{array}$ & & & & $\begin{array}{l}\text { Concordance MZ>DZ, } \\
\text { only for timothy grass }\end{array}$ \\
\hline Hanson (1991) & USA & $17-43$ & $\begin{array}{l}\text { MZ:34 } \\
\mathrm{DZ}: 29\end{array}$ & 0.50 & 0.33 & & Reared together \\
\hline Hanson (1991) & USA & $26-53$ & $\begin{array}{l}\text { MZ:53 } \\
\mathrm{DZ}: 21\end{array}$ & 0.50 & 0 & & Reared apart \\
\hline Sluyter (1998) & Australia & $18-88$ & $\begin{array}{l}\mathrm{MZ}: 79 \\
\mathrm{DZ}: 112\end{array}$ & $0.44^{*}$ & $0.45^{*}$ & & $\begin{array}{l}\text { IgE responses against } \\
\text { components rye grass }\end{array}$ \\
\hline Tovey (1998) & Australia & & $\begin{array}{l}\text { MZ:74 } \\
\text { DZ:68 }\end{array}$ & $\begin{array}{l}0.57^{*} \\
0.65^{*}\end{array}$ & $\begin{array}{l}0.09^{*} \\
0.09^{*}\end{array}$ & & $\begin{array}{l}\text { Including } 317 \text { twinpairs } \\
\text { IgE against components } \\
\text { house dust mite }\end{array}$ \\
\hline
\end{tabular}

*: probandwise concordance

Table 4

Twin Studies of Lung Function

\begin{tabular}{|c|c|c|c|c|c|c|c|}
\hline Study & Population & $\begin{array}{l}\text { Age range } \\
\text { (years) }\end{array}$ & Zygosity & $r_{\mathrm{Mz}}$ & $r_{\mathrm{DZ}}$ & $\mathrm{h}$ & Comments \\
\hline \multicolumn{8}{|l|}{ Skin Test } \\
\hline Hubert (1981) & USA & $42-56$ & $\begin{array}{l}\text { MZ: } 127 \\
\text { DZ: } 141\end{array}$ & 0.71 & 0.33 & 0.77 & No genetic modelling \\
\hline Redline (1987) & USA & $27-61$ & $\begin{array}{l}\text { MZ: } 256 \\
\text { DZ: } 158\end{array}$ & $\begin{array}{l}0.71^{1} \\
0.76^{2}\end{array}$ & $\begin{array}{l}0.16^{1} \\
0.39^{2}\end{array}$ & $0.40-0.75$ & No genetic modelling \\
\hline Kawakami* (1985) & Japan & $16-48$ & $\begin{array}{l}\text { MZ: } 80 \\
\text { DZ: } 22\end{array}$ & & & & No genetic modelling \\
\hline
\end{tabular}

* In the study of Kawakami the FRC (functional residual capacity) and the FVC are determined by genetic influences in adolescence, V50 (flow at $50 \%$ FVC) and V25 (flow at $25 \%$ $\mathrm{FVC}$ ) are determined by genetic influences in adolescence and adulthood.

1 FEV1 (forced expiratory flow in one second)

2 FVC: (forced vital capacity)

of 0.80 in adults, with an AE model providing the best fit to the data. For children the heritability was 0.93 .

Wüthrich et al. (1981) studied a population of 30 monozygotic and 20 dizygotic twin pairs recruited from the Swiss Twin Association and from a sample studied by Schnyder. At least one of each pair of twins had a history of atopy. Total IgE, skin test reactivity and RAST (radioallergo-sorbent) tests were conducted. The concordance of atopy was significantly higher for the monozygotic as compared with the dizygotic twin pairs (57\% vs $20 \%$ ). Although there was a greater tendency of $\log$ serum $\operatorname{IgE}$ levels being more concordant among the monozygotic twin pairs, they were not statistically different between the monozygotic and dizygotic twin pairs.

Total serum IgE levels in 107 twinpairs studied in the earlier-mentioned study by Hopp et al. (1984) showed a significant higher intrapair correlation coefficient in the monozygotic than in the dizygotic twin pairs $(0.82$ and 0.52 respectively). The estimated heritability was 0.61 , showing that genetic influences contribute substantially to the total variance of serum IgE. Hanson et al. (1991) studied 63 US twin pairs reared together, 68 twin pairs reared apart and 2 sets of reared-apart triplets. In addition, 158 reared-together twin pairs derived from the Finnish 
twin registry were investigated. The intraclass correlations for $\log \mathrm{IgE}$ levels were higher among the monozygotic than the dizygotic twin pairs in both the US and Finnish samples. Total IgE level correlations were not different between the monozygotic twin pairs reared apart and the monozygotic twin pairs reared together, suggesting that effects of familial (shared) environment were not very important to the total variance of IgE. The authors used the biometric analysis described by Tellegren (1988). Results of this study showed that the model incorporating additive genetic factors $(\mathrm{A}=0.56 \pm 0.05)$ combined with nonfamilial environment $(E=0.44 \pm 0.05)$ fitted the data best, with no evidence of shared environment.

\section{Specific IgE and Skin Test Reactivity}

Thirty monozygotic and twenty dizygotic twin pairs were studied in the earlier mentioned study of Wüthrich (1981). Skin prick tests and specific IgE were measured against house dust mites (Dermatophagoides pteronyssinus), timothy grass, birch, hazel pollen, hair and epithelia of dogs, cats, horses. The concordance ratio for specific $\operatorname{IgE}$ was not statistically different between monozygotic and dizygotic twin pairs $\left(\chi^{2}=2.84, p>0.05\right)$. When only those pairs of twins are considered in which at least one specific $\mathrm{IgE}$ against an allergen was positive in one twin (probandwise concordance ratio), then monozygotic twin pairs showed a significant concordance $\left(\chi^{2}=4.33,0.01<p<\right.$ $0.05)$. If the specific type of reaction is considered more closely, then the concordance rate for the monozygotic twin pairs for timothy grass is higher than for the dizygotic twin pairs. The other specific IgE levels showed no difference between the monozygotic and dizygotic twin pairs.

In the study of Hopp et al. (1984), intradermal skin testing was performed in 107 twin pairs. This study showed intrapair correlations for total intradermal skin test scores (ISTS) which were significantly higher for the monozygotic twin pairs compared with the dizygotic twin pairs $(0.82$ vs 0.46 respectively), yielding a heritability estimate of 0.72 . Individual skin test reactivity was very variable. From all the antigens tested, only the mixed tree antigen ISTS showed a significant difference between monozygotic and dizygotic twin pairs, yielding a heritability of 0.73 . This study showed that total skin test reactivity is determined more by genetic than environmental influences. Hanson et al. (1991) found no evidence in their study for genetic influence for skin test reactivity and specific $\operatorname{IgE}$ against three allergens. Sluyter et al. (1998) published a twin study from the Australian Health and Medical Research Council Twin Registry, in which 79 monozygotic and 112 dizygotic twin pairs were selected from a large sample of 1597 twin pairs to take part in a test protocol including skin prick testing of 11 common aereallergens including perenial ryegrass. In the selected twin pairs, at least one sibling had a skin prick test to perennial rysgrass greater than $2 \mathrm{~mm}$. Probandwise concordance rates were determined for each IgE-binding component to ryegrass for monozygotic and dizygotic twin pairs where both twins had a skin prick test greater than $3 \mathrm{~mm}$. Probandwise concordance rates were 0.44 for monozygotic and 0.45 for the dizygotic twin pairs. From the 23 individual IgE binding components, compo- nent 15 showed the highest concordance rates for both monozygotic and dizygotic twin pairs ( 0.72 vs 0.68 respectively). The results of this study showed that $\operatorname{IgE}$ responses to specific ryegrass components are determined by environmental influences. IgE responses against house dust mite (Dermatophagoides pteronyssinus, HDM) were examined by the same group in a cohort of 317 twin pairs in which at least one twin had a weak HDM skin test response. Probandwise concordance levels were compared with a subset of 142 twin pairs in which both twins had a skin prick test wheal greater than $3 \mathrm{~mm}$. Thirty-six individual IgE binding components for house dust mites were identified. Although monozygotic twin pairs showed a higher concordance rate than dizygotic twin pairs $(54 \%$ vs $37 \%$, $p$ $<0.0001$ ), only two components (molecular weight $23 \mathrm{kd}$ and $16 \mathrm{kd}$ ) were significantly different between the monozygotic and dizygotic twin pairs. The probandwise concordance rates for the monozygotic and dizygotic twins were respectively 0.57 and 0.09 for the $23 \mathrm{kd}$ component, and 0.64 and 0.09 for the $16 \mathrm{kd}$ component. This study showed that $\mathrm{IgE}$ responses to house dust mite is partly determined by genetic factors, but they are smaller than in the regulation of total IgE (Tovey et al., 1998).

\section{Lung Function}

Lung function indices are determined by body constitution like height, body weight, sex, age and ethnic background. Although all these variables are important, body composition is the most important and highly heritable (Feinleib et al., 1977). Other factors which influence lung function are environmental influences like cigarette smoking, respiratory infections, childhood respiratory illness and occupational dust exposure. The question is, if the genetic variance contributed to lung function is a function of the highly heritable character of body size, or if other genetic factors are important as well.

In 1981 Hubert et al. published a study on lung function in 127 monozygotic and 141 dizygotic twin pairs, who were 42 to 56 years old at the time of examination. Twins were examined in three study centers (California, San Francisco and Los Angeles). Lung function forced vital capacity (FVC) and forced expiratory flow in one second (FEV1) tests were performed on each subject. The intraclass correlation of FVC was 0.72 for monozygotic twin pairs and 0.16 for dizygotic twin pairs, yielding a heritability of 0.91 . The intraclass correlation of FEV1 was 0.71 for the monozygotic twinpairs and 0.33 for the dizygotic twin pairs; the estimated heritability was 0.77 . Lung function was adjusted for age, weight and height. If other variables were considered, like smoking, the heritability of FEV1 was still 0.74 . In order to test whether heritability was overestimated in monozygotic twins due to greater similarity of shared environment, re-analyses of FEV1 were adjusted for all associated characteristics and stratified by the question "how frequently do you and your twin get together?". This showed a heritability of FEV1 ranging from 0.52 to 0.80 , dependent on how often the twins saw each other. This study showed substantial evidence for genetic contribution to lung function regardless of many associated characters including body constitution. Another study published by 
Redline et al., (1987) from the Greater Boston Twin registry of 257 monozygotic and 158 dizygotic twin pairs showed heritability estimates as much as $0.40-0.75$, adjusted for smoking and other environmental and familial influences, including body constitution. These and several other twin studies showed that the variance of lung function is significant explained by genetic factors other than body constitution (Hankins et al., 1982; Kawakami et al., 1985).

\section{Discussion}

The present review has shown that hereditary influences are important in the pathogenesis of asthma. Family studies going back to the beginning of the last century described the hereditary nature of asthma. Although Francis Galton is considered as the father of the twin method, the first descriptions of the twin method appeared in an article by Curtis Merriman and Hermann Siemens (Rende et al., 1990) in the mid-1920s, and nowadays twin studies have been very useful in dissecting the genetic architecture of complex traits like asthma.

The twin studies summarized above have shown a considerable genetic component of asthma, in which the genetic effects are mainly additive. In particular, the largescale twin studies based on questionnaires are unanimous in their outcome, showing additive genetic effects and individual specific environment contribute significantly to the variance of asthma. This is in accordance with the overwhelming evidence of many genes regulating the pathogenesis of this condition. Many linkage and association studies have identified chromosomal regions that may contain genes that contribute to asthma: chromosome $5 \mathrm{q}$, $11 \mathrm{q}, 12 \mathrm{q}, 6 \mathrm{p} 21.3,12 \mathrm{q} 14.3$ and $14 \mathrm{q} 11.2-13$. There are not many twin studies which have studied the intermediate phenotypes of asthma and most studies are small. In most of these studies genetic modelling has not been carried out and no statement on the mode of inheritance could be made, although in several studies immunoglobulin E appeared to be determined by additive genetic factors and nonshared environment. Most studies on bronchial hyperresponsiveness and immunoglobulin $\mathrm{E}$ showed extensive evidence for genetic influences, with estimated heritabilities of 0.66 for bronchial hyperresponsiveness and 0.58-0.79 for immunoglobulin E. In the study of Bazaral et al. (1974), a difference in heritability between children and adults was found, furthermore in the study of clinical diagnosis asthma from Nieminen et al. (1991) there was evidence that heritability decreases with age. So there may be differences between children and adults according to the genetic variance of asthma and total $\mathrm{IgE}$, but future studies should pay attention to this problem. The IgE studies in twins are in accordance with segregation studies in families with respect to the hereditary outcome, although the estimates of heritabilities are lower in the segregation studies: 0.27-0.43 (Gerrard et al., 1978; Lawrence et al., 1994; Meyers et al., 1987), compared with the twin studies. Twin studies about specific IgE against aeroallergens and skin test reactivity showed that environmental influences contribute more than genetic influences to the variance of these traits. The two most recent studies from Sluyter et al. (1998) and
Tovey et al. (1998) showed the importance of environment, but found a higher concordance rate for specific IgEbinding sites for house dust mite in monozygotic twin pairs compared with dizygotic twin pairs, showing that genetic influences may be of importance.

An important finding in many twin studies in different parts of the world is that shared environment even in young twins does not explain the familial patterns seen for asthma. This finding seems in contrast with results from epidemiological studies that show viruses, smoking behavior, indoor-outdoor pollution, and house dust mites to be risk factors for the development of asthma that are shared by siblings. One possibility is that shared environment influences only lead to asthma or other traits when the subject also has a phenotype that predisposes to the disorder. This type of genotype-environment interaction will be "hidden" in the genetic component of the disease, showing a higher heritability and no significant evidence for shared environment. This hypothesis is supported by animal literature which shows that sensitivity to the environment is itself under genetic control. It means that there are genes which affect the phenotype in such a way that a subject is more or less sensitive to a particular environment (Martin et al., 1987). In case of asthma and intermediate phenotypes, this question remains to be answered and to our knowledge there are no available studies which have addressed this problem.

Another possible cause for finding evidence of shared environment in most twin studies is the twin method itself. Whether family clustering in case of asthma and related phenotypes is due to genetic inheritance, environmental influences, genetic-environment interaction, shared nongenetic factors or even interaction between these items is a puzzling question. The twin method is a potentially useful method to unravel these parameters, but statistical models are probably biased towards a genetic explanation. Under the classical twin model, any excess in monozygotic correlation compared to dizygotic correlation is interpreted as being due to genes. So shared environment may be "hidden" in shared genetic effects, because one can never be sure that environmental effects shared within monozygotic twin pairs are greater than within dizygotic twin pairs (Hopper et al., 2000).

Many questions remain regarding whether the same genes are involved in asthma, bronchial hyperresponsiveness and atopy, how these genes interact with the environment, whether the same or different genes are involved before or after the development of irreversible airway obstruction, and whether there is an age-related gene expression in asthma. These questions can be solved by using twins in longitudinal studies (Harris et al., 1998). The use of monozygotic twins and the co-twin control study designs are suitable to study the effect between genes and environment (Duffy et al., 1998; Martin, 2000).

\section{Conclusions}

Twin studies have been very useful in dissecting the genetic architecture of asthma and related phenotypes. Not only in the genetic but maybe more in the environmental architecture of asthma lies a considerable challenge for the future 
which can be solved by twin studies. In order to find stillundiscovered genes and to resolve the genetic-environment interaction which plays a role in the pathogenesis of asthma, exchange of information and collaboration between groups involved in the genetics of asthma is a very important issue.

\section{Acknowledgements}

H. Los was supported by a grant from Astra-Zeneca: Astra stipendium 1993.

\section{$\overline{\text { References }}$}

A genome-wide search for asthma susceptibility loci in ethnically diverse populations. The collaborative study on the genetics of asthma (CSGA). (1997). Nature Genetics, 26, 389-392.

American Thoracic Society. (1987). Standards for the Diagnosis and Care of Patients with Chronic Obstructive Pulmonary Disease (COPD) and Asthma. November 1986. American Review of Respiratory Disease, 136, 225-244.

Barnes, K.C., Neely, J.D., Duffy, D.L., Freidhoff, L.R., Breazeale, D.R., Schou, C., Naidu, R.P., Levett, P.N., Renault, B., Kucherlapati, R., Iozzino, S., Ehrlich, E., Beaty, T.H., \& Marsh, D.G. (1996). Linkage of asthma and total serum IgE concentration to markers on chromosome 12q: evidence from Afro-Caribbean and Caucasian populations. Genomics, 37, $41-50$.

Bazaral, M., Orgel, H.A., \& Hamburger, R.N. (1974). Genetics of IgE and Allergy: Serum IgE levels in twins. Journal of Allergy and Clinical Immunology, 54, 288-304.

Boomsma, D.I., Kaptein, A., Kempen, A., Gevers-Leuven, J., \& Princen, H.M.G. (1993). Lipoprotein (a): relation to other risk factors and genetic heritability. Results from a Dutch parent-twin study. Atherosclerosis, 99, 23-33.

Bousquet, J., Chanez, P., Lacoste, J.Y., Barneon, G., Ghavanian, N., Enander, I., Venge, P., Ahlstedt, S., Simony-Lafontaine, J., Godard, P., et al., (1990). Eosinophilic inflammation in asthma. New England Journal of Medicine, 323, 1033-1939.

Burney, P., Chinn, S., Luczynska, C., Jarvis, D., \& Lai, E. (1996). Variations in the prevalence of respiratory symptoms, selfreported asthma attacks, and the use of asthma medication in the European Community Respiratory Health Survey (ECRHS). European Respiratory Journal, 9, 697-695.

Burr, M.L., Butland, B.K., King, S., \& Vaughan-Williams, E. (1989). Changes in asthma prevalence: two surveys 15 years apart. Archives of Disease in Childhood, 64, 1452-1456.

Cantor, R.M., \& Rotter, J.I. (1992). Analysis of genetic data: Methods and Interpretation. The Genetic Basis of Common Disease (Chapter 4). Oxford: Oxford University Press.

Carmelli, D., Swan, G.E., Robinette, D., \& Fabsitz, R. (1992). Genetic influence on smoking - a study of male twins. New England Journal of Medicine, 327, 829-833.

Cerveri, I., Bruschi, C., Ricciardi, M., Zocchi, L., Zoia, M.C., \& Rampulla, C. (1987). Epidemiological diagnosis of asthma: methodological considerations of prevalence evaluation. European Journal of Epidemiology, 3, 202-205.

Chen, W.J., Chang, H.W., Wu, M.Z., Lin, C.C.H., Chang, C., Chiu, Y.N., \& Soong, W.T. (1999). Diagnosis of zygosity by questionnaire and polymarker polymerase chain reaction in young twins. Behavior Genetics, 29, 115-123.
Chen, Y., Rennie, D.C., Lockinger, L.A., \& Dosman, J.A. (1998). Evidence for major genetic control of wheeze in relation to history of respiratory allergy: Humboldt Family Study. American Journal of Medical Genetics, 75, 485-491.

Collee, J.M., ten Kate, L.P., de Vries, H.G., Kliphuis, J.W., Bouman, K., Scheffer, H., \& Gerritsen J. (1993). Allele sharing on chromosome $11 \mathrm{q} 13$ in sibs with asthma and atopy. Lancet, 342, 936.

Cooke, R.A., \& van der Veer, A. Jr. (1916). Human sensitization. Journal of Immunology, 1, 201-305.

Cookson WO, \& Moffatt MF. (1997). Asthma: an epidemic in the absence of infection? Science, 275, 41-42.

Cookson, W.O., Sharp, P.A., Faux, J.A., \& Hopkin, J.M. (1989). Linkage between immunoglobulin $\mathrm{E}$ responses underlying asthma and rhinitis and chromosome $11 \mathrm{q}$. Lancet, 1, 1292-1295.

Daniels, S.E., Bhattacharrya, S., James, A.J., Leaves, N.I., Young, A., Hill, M.R., Faux, J.A., Ryan, G.F., le Souef, P.N., Lathrop, G.M., Musk, A.W., \& Cookson, W.O. (1996). A genomewide search for quantitative loci underlying asthma. Nature, $383,247-250$.

de Marco, R., Cerveri, I., Bugiani, M., Ferrari, M., \& Verlato, G. (1998). An undetected burden of asthma in Italy: relation between clinical and epidemiological diagnosis of asthma. European Respiratory Journal, 11, 599-605.

Doull, I.J.M., Lawrence, S., Watson, M., Begishvili, R.W., Beasley, R.W., Lampe, F., Holgate, S.T., \& Morton, N.E. (1996). Allelic association of gene markers on chromosome $5 q$ and $11 \mathrm{q}$ with atopy and bronchial hyperresponsiveness. American Journal of Respiratory and Critical Care Medicine, 153, 1280-1284.

Drinkwater, H. (1909). Mendelian heredity in asthma. British Medical Journal, 1, 88.

Duffy, D.L. (1994). Asthma and allergic diseases in Australian twins and their families. PhD Thesis (unpublished). Brisbane, Australia: Department of Medicine, University of Queensland.

Duffy, D.L., Martin, N.G., Battistutta, D., Hopper, J.L., \& Mathews, J.D. (1990). Genetics of asthma and hayfever in Australian twins. American Review of Respiratory Disease, 142, 1351-1358.

Duffy, D.L., Mitchell, C.A., \& Martin, N. (1998). Genetic and environmental risk factors for asthma. A co-twin control study. American Journal of Respiratory and Critical Care Medicine, 157, 840-845.

Edfors-Lubs, M.L. (1971). Allergy in 7000 twin pairs. Acta Allergologica, 26, 249-285.

Enarson, D.A., Vedal, S., Schulzer, M., Dybuncio, A., \& ChanYeung, M. (1987). Asthma, asthma-like symptoms, chronic bronchitis and the degree of bronchial hyperresponsiveness in epidemiological surveys. American Review of Respiratory Disease, 136, 613-617.

European Community Respiratory Health Group. (1997). Genes for asthma? An analysis of the European Community Respiratory Health Survey. American Journal of Respiratory and Critical Care Medicine, 156, 1773-1780.

Feinleib, M., Garrison, R.J., Fabsitz, R., Christian, J.C., Hrubec, Z., Borhani, N.O., Kannel, W.B., Rosenman, R., Schwartz, J.T., \& Wagner, J.O. (1977). The NHLBI twin study of car- 
diovascular disease risk factors: methodology and summary of results. American Journal of Epidemiology, 106, 153-172.

Gerrard, J.W., Rao, D.C., \& Morton, N.E. (1978). A genetic study of immunoglobulin E. American Journal of Human Genetics, 30, 46-58.

Hall, I.P., Wheatley, A., Wilding, P., \& Liggett, S.B. (1995). Association of Glu 27 beta-2-adrenoceptor polymorphism with lower airway reactivity in asthmatic subjects. Lancet, $345,1213-1214$.

Hankins, D., Drage, C., Zamel, N., \& Kronenberg, R. (1982). Pulmonary function in identical twins raised apart. American Review of Respiratory Disease, 125, 119-121.

Hanson, B., McGue, M., Roitman-Johnson, B., Segal, N.L., Bouchard, T.J., \& Blumenthal, M.N. (1991). Atopic disease and immunoglobulin $\mathrm{E}$ in twins reared apart and together. American Journal of Human Genetics, 48, 873-879.

Harris, J.R., Magnus, P., Samuelsen, S.O., \& Tambs, K. (1997). No evidence for effects of family environment on asthma. A retrospective study of Norwegian twins. American Journal of Respiratory and Critical Care Medicine, 156, 43-49.

Harris, J.R., Nystad, W., \& Magnus, P. (1998). Using genes and environments to define asthma and related phenotypes: applications to multivariate data. Clinical and Experimental Allergy, $28,43-45$.

Haseman, J.K., \& Elston, R.C. (1970). The estimation of genetic variance from twin data. Behavior Genetics, 1, 11.

Hasstedt, S.J., Meyers, D.A., \& Marsh, D.G. (1983). Inheritance of immunoglobulin E: genetic model fitting. American Journal of Medical Genetics, 14, 61-66.

Hettema, J.M., Neale, M.C., \& Kendler, K.S. (1995). Physical similarity and the equal-environment assumption in twin studies of psychiatric disorders. Behavior Genetics, 25, 226-327.

Holberg, C.J., Elston, R.C., Halonen, M., Wright, A.L., Taussig, L.M., Morgan, W.J., \& Martinez, F.D. (1996). Segregation analysis of physician-diagnosed asthma in Hispanic and nonHispanic white families. A recessive component? American Journal of Respiratory and Critical Care Medicine, 154, $144-150$.

Holgate, S.T. (1997). Asthma genetics: waiting to exhale. Nature Genetics, 15, 227-229.

Hopp, R.J., Bewtra, K., Watt, G.D., Nair, N.M., \& Townley, R.G. (1984). Genetic analysis of allergic disease in twins. Journal of Allergy and Clinical Immunology, 73, 265-270.

Hopper, J.L. (2000). Why 'common environmental effects' are so uncommon in the literature. In T.D. Spector, H. Snieder, \& A.J. MacGregor (Eds.) Advances in twin and sib-pair analysis (pp 151-165). Oxford: Oxford University Press.

Hopper, J.L., Hannah, M.C., Macaskill, G.T., \& Mathews, J.D. (1990). Twin concordance for a binary trait: III. A bivariate analysis of hayfever and asthma. Genetic Epidemiology, 7, 277-289.

Howard, T.D., Wiesch, D.G., Koppelman, G.H., Postma, D.S., Meyers, D.A., \& Bleecker, E.R. (1999). Genetics of allergy and bronchial hyperresponsiveness. Clinical and Experimental Allergy, 29 (Suppl 2), 86-89.

Hubert, H.B., Fabsitz, R.R., Feinleib, M., \& Gwinn, C. (1982). Genetic and environmental influences on pulmonary function in adult twins. American Review of Respiratory Disease, 125, 409-415.

Jenkins, M.A., Hopper, J.L., \& Giles, G.G. (1997). Regressive logistic modeling of familial aggregation for asthma in 7,384 population-based nuclear families. Genetic Epidemiology, 14, 317-322.

Kawakami, Y., Shida, A., Yanamoto, H., \& Yoshikawa, T. (1985). Pattern of genetic influence on pulmonary function. Chest, 87, 507-511.

Keeley DJ, Neill P, \& Gallivan S. (1991). Comparison of the prevalence of reversible airways obstruction in rural and urban Zimbabwean children. Thorax, 46, 549-553.

Kendler, K.S. (1993). Twin studies of psychiatric illness. Current status and future directions. Archives of General Psychiatry, 50, 905-915.

Kerkhof, M., De Graaf, A., \& Droste, J.H.J. (1994). Prevalentie van astmatische klachten in drie regio's in Nederland. Tijdschr Soc Gezondheidsz, 72, 181-185.

Khoury, M.J., Cohen, B.H., \& Beaty, T.H. (1993). Fundamentals of Genetic Epidemiology. Oxford: Oxford University Press.

König, P., \& Godfrey, S. (1974). Exercise-induced bronchial lability in monozygotic (identical) and dizygotic (nonidentical) twins. Journal of Allergy and Clinical Immunology, 54, 280-287.

Koppelman, G.H., Stine, O.C., Howard, T.D., Xu, J., Meijer, G.G., Postma, D.S., Bleecker, E.R., \& Meyers, D.A. (1998). Genome screen for asthma susceptibility loci in a restricted Dutch population (Abstract). American Journal of Human Genetics, 63 (Suppl), 1705.

Laitinen, T., Rasanen, M., Kaprio, J., Koskenvuo, M., \& Laitinen, M. (1998). Importance of genetic factors in adolescent asthma. American Journal of Respiratory and Critical Care Medicine, 157, 1073-1078.

Lawrence, S., Beasley, R., Doull, I., Begishvili, B., Lampe, F., Holgate, S.T., \& Morton, N.E. (1994). Genetic analysis of atopy and asthma as quantitative traits and ordered polychotomies. Annals of Human Genetics, 58, 359-368.

Lichtenstein, P., \& Svartengren, M. (1997). Genes, environments and sex: factors of importance in atopic diseases in 7-9 year old Swedish twins. Allergy, 52, 1079-1086.

Manian, P. (1997). Genetics of asthma: A review. Chest, 112, 1397-1408.

Marsh, D.G., Neely, J.D., Breazeale, D.R., Ghosh, B., Freidhoff, L.R., Ehrlich-Kautzky, E., Schou, C., Krishnaswamy, G., \& Beaty, T.H. (1994). Linkage analysis of IL-4 and other chromosome 5q31.1 markers and total immunoglobulin E concentrations. Science, 264, 1152-1156.

Martin, N. (2000). Gene-environment interaction and twin studies. In T.D. Spector, H. Snieder, \& A.J. MacGregor (Eds.), Advances in twin and sib-pair analysis (pp. 144-150). Oxford: Oxford University Press.

Martin, N.G., Eaves, L.J., \& Heath, A.C. (1987). Prospects for detecting genotype $\mathrm{x}$ environment interactions in twins with breast cancer. Acta Geneticae Medicae et Gemellologiae, 36, 5-20.

Martinez, F.D. (1997). Complexities of the genetics of asthma. American Journal of Respiratory and Critical Care Medicine, 156, S117-S122.

Martinez, F.D., Wright, A.L., Taussig, L.M., Holberg, C.J., Halonen, M., \& Morgan, W.J. (1995). Asthma and wheezing 
in the first six years of life. New England Journal of Medicine, 332, 133-138.

Meneely, G.R., Renzetti, A.D., Steel, J.D., Wyatt, J.P., \& Harris, H.W. (1962). Chronic bronchitis, asthma and pulmonary emphysema. American Review of Respiratory Disease, 85, 762-768.

Mensinga, T.T., Schouten, J.P., Rijcken, B., Weiss, S.T., Speizer, F.E., \& van der Lende, R. (1990). The relationship of eosinophilia and positive skin test reactivity to respiratory symptom prevalence in a community-based population study. Journal of Allergy and Clinical Immunology, 86, 99-107.

Meyers, D.A., Beaty, T.H., Freidhoff, L.R., \& Marsh, D.G. (1987). Inheritance of total serum IgE (basal levels) in man. American Journal of Human Genetics, 41, 51-62.

Meyers, D.A., Postma, D.S., \& Panhuysen, C.I.M. (1994). Evidence for a locus regulating total serum IgE levels mapping to chromosome 5. Genomics, 23, 464-470.

Moffatt, M.F., Sharp, P.A., Faux, J.A., Young, R.P., Cookson, W.O., \& Hopkin, J.M. (1992). Factors confounding genetic linkage between atopy and chromosome 11q. Clinical and Experimental Allergy, 22, 1046-1051.

Morton, N.E. (1955). Sequential tests for the detection of linkage. American Journal of Human Genetics, 7, 277-318.

Newman-Taylor, A. (1995). Environmental determinants of asthma. Lancet, 345, 296-299.

Nieminen, M.M., Kaprio, J., \& Koskenvuo, M. (1991). A population-based study of bronchial asthma in adult twin pairs. Chest, 100, 70-75.

Ninan, T.K., \& Russell G. (1992). Respiratory symptoms and atopy in Aberdeen schoolchildren: evidence from two surveys 25 years apart. British Medical Journal, 304, 873-875.

Noguchi, E., Shibasaki, M., Arinami, T., Takeda, K., Maki, T., Miyamoto, T., Kawashima, T., Kobayashi, K., \& Hamaguchi, H. (1997). Evidence for linkage between asthma/atopy and chromosome 5q31-33 in a Japanese population. American Journal of Respiratory and Critical Care Medicine, 156, 1390-1393.

Ober, C., Cox, N.J., Abney, M., Di Rienzo, A., Lander, E.S., Changyaleket, B., Gidley, H., Kurtz, B., Lee, J., Nance, M., Pettersson, A., Prescott, J., Richardson, A., Schlenker, E., Summerhill, E., Willadsen, S., \& Parry, R. (1998). Genomewide search for asthma susceptibility loci in a founder population. The Collaborative Study on the Genetics of Asthma. Human Molecular Genetics, 7, 1393-1398.

Panhuysen, C.I., Bleecker, E.R., Koëter, G.H., Meyers, D.A., \& Postma, D.S. (1998). Characterization of obstructive airway disease in family members of probands with asthma. An algorithm for the diagnosis of asthma. American Journal of Respiratory and Critical Care Medicine, 157, 1734-1742.

Panhuysen, C.I.M., \& Meyers, D.A. (1996). Genetic regulation of total serum IgE levels. In S.B. Liggett \& D.A. Meyers (Eds.), Genetics of Asthma (pp. 511-523). New York: Marcel Dekker Inc.

Peat, J.K., van den Berg, R.H., Green, W.F., Mellis, C.M., Leeder, S.R., \& Woolcock, A.J. (1994). Changing prevalence of asthma in Australian children. British Medical Journal, 308, 1591-1596.

Platts-Mills, T.A., \& Carter, M.C. (1997). Asthma and indoor exposure to allergens. New England Journal of Medicine, 8, 1382-1384.
Postma, D.S., Bleecker, E.R., Amelung, P.J., Holroyd, K.J., Xu, J., Panhuysen, C.I.M., Meyers, D.A., \& Levitt, R.C. (1995). Genetic susceptibility to asthma-bronchial hyperresponsiveness coinherited with a major gene for atopy. New England Journal of Medicine, 333, 894-900.

Postma, D.S., Meijer, G.G., \& Koppelman, G.H. (1998). Definition of asthma: possible approaches in genetic studies. Clinical and Experimental Allergy, 28 Suppl 1, 62-64.

Rackemann, F.M. (1928). Studies in asthma. II. An analysis of two hundred and thirteen cases in which the patients were relieved for more than two years. Archives of Internal Medicine, 41, 346-369.

Redline, S., Tishler, P.V., Lewitter, F.I., Tager, I.B., Munoz, A., \& Speizer, F.E. (1987). Assessment of genetic and nongenetic influences on pulmonary function. American Review of Respiratory Disease, 135, 217-222.

Rende, R.D., Plomin, R., \& Vandenberg, S.G. (1990). Who discovered the twin method? Behavior Genetics, 20, 277-285.

Rijcken, B., Kerkhof, M., \& de Graaf, A. (1996). Europees Luchtweg Onderzoek Nederland (ELON). Groningen: Rijksuniversiteit Groningen.

Robertson, C.F., Heycock, E., Bishop, J., Nolan, T., Olinsky, A., \& Phelan, P.D. (1991). Prevalence of asthma in Melbourne schoolchildren: changes over 26 years. British Medical Journal, 302, 1116-1118.

Sandford, A., Weir, T., \& Pare, P. (1996). The genetics of asthma. American Journal of Respiratory and Critical Care Medicine, 153, 1749-1765.

Schork, N.J. (1997). Genetics of complex disease. approaches, problems and solutions. American Journal of Respiratory and Critical Care Medicine, 156, S103-S109.

Schwartz, M. (1952). Heredity in bronchial asthma. Acta Allergologica, 5 (Suppl. II), 1-19.

Sluyter, R., Tovey, E.R., Duffy, D.L., \& Britton, W.J. (1998). Limited genetic control of specific IgE responses to rye grass pollen allergens in Australian twins. Clinical and Experimental Allergy, 28, 322-331.

Skadhauge, L.R., Christensen, K., Kyvik, K.O., \& Sigsgaard, T. (1999). Genetic and environmental influence on asthma: a population based study of 11.688 Danish twin pairs. European Respiratory Journal, 13, 8-14.

Spain, W.C., \& Cooke, R.A. (1924). Studies in specific hypersensitiveness. XI. The familial occurrence of hayfever and bronchial asthma. Journal of Immunology, 9, 521-569.

Tellegen, A., Lykken, D.T., Bouchard, T.J., Wilcox, K.J., Segal, N.L., \& Rich, S. (1998). Personality similarity in twins reared apart and together. Journal of Personality and Social Psychology, 54, 1036-1039.

Townley, R.G., Bewtra, A., Wilson, A.F., Hopp, R.J., Elston, R.C., Nair, N., \& Watt, G.D. (1986). Segregation analysis of bronchial response to metacholine inhalation challenge in families with and without asthma. Journal of Allergy and Clinical Immunology, 77, 101-107.

Tovey, E.R., Sluyter, R., Duffy, D.L., \& Britton, W.J. (1998). Immunoblotting analysis of twin sera provides evidence for limited genetic control of specific $\operatorname{IgE}$ to house dust mite allergens. Journal of Allergy and Clinical Immunology, 101, 491-497. 
Turkeltaub, P.C., \& Gergen, P.J. (1991). Prevalence of upper and lower respiratory conditions in the US population by social and environmental factors: data from the second National Health and Nutrition Examination Survey, 1976 to 1980 (NHANES II). Annals of Allergy, 67, 147-154.

Von Mutius, E., Martinez, F.D., Fritzsch, C., Nicolai, T., Roell, G., \& Thiemann, H.H. (1994). Prevalence of asthma and atopy in two areas of West and East Germany. American Journal of Respiratory and Critical Care Medicine, 149, 358-364.
Waite DA, Eyles EF, Tarkin SL, \& O’Donnell TV. (1980). Asthma prevalence in Tokelauan children in two environments. Clinical Allergy, 10, 71-75.

Woolcock, A.J., Peat, J.K., Salome, C.M., Yan, K., Anderson, S.D., Schoeffel, R.E., McCowage, G., \& Killalea, T. (1987). Prevalence of bronchial hyperresponsiveness and asthma in a rural adult population. Thorax, 42, 361-368.

Wüthrich, B., Baumann, E., Fries, R.A., \& Schnyder, U.W. (1981). Total and specific IgE (RAST) in atopic twins. Clinical Allergy, 11, 147-154. 